\title{
Electric Vehicle Penetration in Distribution Network: A Swedish Case Study
}

\author{
Henrik Maninnerby ${ }^{1}$, Sune Bergerland ${ }^{2}$, Stavros Lazarou ${ }^{3}\left(\mathbb{D}\right.$ and Andreas Theocharis ${ }^{4, *}$ \\ 1 Studentwork AB, 11218 Stockholm, Sweden \\ 2 Karlstads El- och Stadsnät AB, 65184 Stockholm, Sweden \\ 3 Department of Electrical and Electronic Engineering Educators, School of Pedagogical \& Technological \\ Education (ASPETE), 14121 Heraklion, Greece \\ 4 Department of Electrical Engineering, Karlstad University, 65188 Karlstad, Sweden \\ * Correspondence: andreas.theocharis@kau.se
}

Received: 24 April 2019; Accepted: 26 June 2019; Published: 28 June 2019

check for updates

\begin{abstract}
This study aims to simulate the use of renewable energy in the form of different energy sources, such as solar cells, district heating, and in the presence of battery storage and for high penetration of electric vehicles in a typical Swedish power grid. The EnergyPLAN software is used. The purpose is to examine the demands in order to cope with the needs that may arise and to create a better understanding of how renewable energy affects the power balance and future investments in the case of a typical Swedish distribution system. The importance of this research is mainly based on the fact that it represents a real network, as it operates today, which is analyzed using the expected electric vehicle penetration. The aim is to investigate the expansion needs for maintaining the current quality for service despite the addition of new loads. In addition, the regional and national special regulatory and operational requirements are taken into account and described in this work.
\end{abstract}

Keywords: renewable energy sources; electric vehicles; EnergyPLAN; distribution grid; distributed generation

\section{Introduction}

As a consequence of the United Nations' (UN) latest agreement in Paris in December 2015 on climate changes [1,2] as well as due to the rapidly public increasing interest on Electric Vehicles (EVs), a number of European countries, including Sweden, and some states in the USA agreed to expand the market for EVs as an effort to reduce the amount of greenhouse gases [3]. As analyzed by Morais et al. [4], if the number of EVs increases dramatically in Sweden, the electricity system could be possibly burdened. The problem might be even more intensive in a particular case where the owners of EVs would like to charge with higher currents than 10 A single-phase charging, which is typical today for a Swedish large customer. These barriers are better explained by Knezovic et al. [5]. An extensive assessment of urban networks is provided by Fichera et al. [6]. However, EVs could provide ancillary power system services alleviating constraints [7] and congestions [8].

In Sweden, electricity consumption is mostly affected by cold winters, especially in areas where space heating is based on electrical units. In particular, in Karlstad, where the presented case study takes place, only about $5 \%$ of the households are not heated by electrical units. Sweden's power companies are regulated by the Energy Market Inspectorate, "Energimarknadsinspektionen", to ensure that fees paid by the power companies' customers are maintained at a reasonable level [9].

According to Statistics in Sweden [10], the number of cars, buses, and trucks fully powered by electricity was around 290 at the end of 2008. If electric hybrid (EHs) vehicles were included, the corresponding number increases to approximately 13,800 vehicles, which could be connected to 
the grid following, according to a study from de Durana et al. [11]. According to the same statistics, the amount of pure EVs was slightly more than 11,100 at the end of 2017 and, including EHs, the amount increases to more than 115,000. In 2017, almost 39,000 fully or partially EVs were registered in Sweden, which results in almost $34 \%$ of the total new registered vehicles. This indicates that the number of EVs and EHs will only increase over the next few years. Moreover, EHs contribute to the largest increment with almost $50 \%$ of the total over the last five years. Except from EVs, Plug-in EHs could also contribute to power system balancing [12].

It is of paramount importance for electrical grid owners, electrical grid operators, and all involved stakeholders to have an integrated knowledge with regard to future electrical power needs in order to establish a safe strategy for grid investments and new business models. As such, several future scenarios are explored in order to define suitable strategies toward a feasible solution with high penetration of renewable energy systems (RES), EVs, and energy storage devices (ESD) [13,14]. In Reference [13], the prospects for realization of the $100 \%$ renewable energy system in North Macedonia by making use of the EnergyPLAN model is investigated. In the first scenario, a 50\% RES has been created for the year 2030 as a first step toward the 100\% future RES. In the second scenario, a 100\% RES in the year 2050 has been designed. In Reference [14], a study is presented toward a 100\% RES for Ireland based on the EnergyPLAN, since it accounts for all sectors of the energy that need to be taken into account for the integration of renewable sources such as the electricity, the heat, and the transport sectors. The investigation has been conducted by developing three different $100 \%$ RES with each focusing on a different resource. Specifically, biomass, hydrogen, and electricity resources have been used and compared with reference to the existing Irish energy system. There are several similar investigations based on future scenarios toward the development of a 100\% RES. Each particular case study is unique because it includes its own special characteristics and requirements.

The aim of this paper is to investigate several scenarios to achieve an electrical power balance under high penetration of EVs in the Swedish distribution system. Specifically, this study is based on a real system and its findings were applied to this network, instead of being applied to a generalized approach [15]. The investigated area is Henstad/Hultsberg in the northwest of Karlstad, Sweden, in the Karlstads El- och Stadsnät's power network. Several scenarios have been developed and simulated. The parameters that configure the scenarios are (i) the number of grids connected EVs, (ii) the level of charging rate, (iii) the charging profile, (iv) the flexible demand, and (v) the district heating versus heating using electrical units. Moreover, the case of residential PV systems is included when they are used for household demands. The purpose of the paper is to simulate the development of RES in the presence of different sources, such as PVs, district heating, and ESD. The presented analysis has been conducted by using the EnergyPLAN software in References [16] and [17], which offer a proven research tool. This particular city area has been selected for the study in order to investigate the vulnerability for electricity shortages in case of high penetration of EVs and distributed generation [18]. The purpose of the paper is to simulate the development of RES in the presence of different sources, such as PVs, district heating, and ESD. As such, the impact of high EVs penetration to the power network is elaborated and a better understanding of potential required measures and grid investments for the feasible operation of the RES are demonstrated.

\section{Materials and Methods}

\subsection{The EnergyPLAN Software}

EnergyPLAN simulates the operation of large-scale energy systems on an hourly basis, including the electricity, heating, cooling, industry, and transport sectors. The EnergyPLAN [16] is a simulation software for renewable energy integration studies, initially developed by Ph.D. Henrik Lund at Aalborg University in 1999. Since then, the program has been improved, updated, and, thus, expanded with many new features to its current version, 132, as several companies and other universities participate 
in the project. Among other things, the main capabilities of the program are to assist in the design of new power networks as well as the analysis of the energy impact of different energy strategies.

The results of the simulations can be obtained in a few different ways. Through Run (Clipboard), the data is copied, which can be pasted into Microsoft Excel for further processing. The Run (Display) shows the same data in the form of a box that appears on the screen. Run (Print) prints the data on a specified printer and Run (Serial) allows running up to eleven values of RES to review the changes. For example, it is possible to see how different amounts of power from solar panels affect the total critical overproduction of electricity, fuel, exports and imports of electricity, $\mathrm{CO}_{2}$, costs, and more. However, this function only shows the corresponding value without considering fluctuations during the year.

\subsection{The Primary Data of the Simulation}

This study has been conducted for Karlstads El- och Stadsnät, Henstad/Hultsberg area in the Karlstad power network. Initially, it was necessary to find out what transformers are in the area. Based on the data available from Karlstads El- och Stadsnät and searching streets using local maps, fifteen transformers were found to supply the neighborhood. The corresponding data are given in Table 1.

Table 1. The various transformers of the area.

\begin{tabular}{ccccc}
\hline Label & $\begin{array}{c}\text { Transformer } \\
\text { Power (kVA) }\end{array}$ & $\mathbf{8 0 \%}$ (kVA) & Connected Customers & $\begin{array}{c}\text { Connected } \\
\text { Customers with } \\
\text { Electrical Heating }\end{array}$ \\
\hline T261 & 800 & 640 & 66 & 56 \\
T262 & 800 & 640 & 55 & 36 \\
T270 & 800 & 640 & 61 & 61 \\
T271 & 800 & 640 & 57 & 57 \\
T272 & 500 & 400 & 42 & 42 \\
T273 & 500 & 400 & 44 & 43 \\
T274 & 500 & 400 & 49 & 49 \\
T280 & 800 & 640 & 59 & 58 \\
T281 & 800 & 640 & 58 & 58 \\
T282 & 800 & 640 & 66 & 66 \\
T283 & 800 & 640 & 67 & 67 \\
T288 & 315 & 252 & 21 & 20 \\
T289 & 800 & 640 & 30 & 29 \\
T290 & 800 & 640 & 68 & 68 \\
T422 & 315 & 252 & 1 & 0 \\
\hline
\end{tabular}

Although the transformers can be utilized at $100 \%$ capacity, Karlstads El- och Stadsnät, has set a limit of $80 \%$ utilization rate to ensure that the life expectancy of the transformers is not affected. This is a special characteristic of this utility not usually met by other system operators. The remaining $20 \%$ are used to deal with reactive power and other problems that may occur. In Figures 1-3, one can see the different power demands for the respective transformers' capacities.

This study focuses on four consecutive transformers (on the same line) to slightly limit the workload. Therefore, the four transformers T261, T262, T273, and T422 were selected since they seem to contain one of every kind of transformer capacity of those in the area. By comparing the transformers in Figures 1-3, it can be seen that they all have reasonably similar power demands.

The power curves are calculated by taking each transformer's maximum power consumption at every hour in 2017, comparing them with the coldest year that data is available for (2010), and creating a new table with the highest values for each hour. These new values are used as the basis for power demand in the simulation and are given in Table 2. 


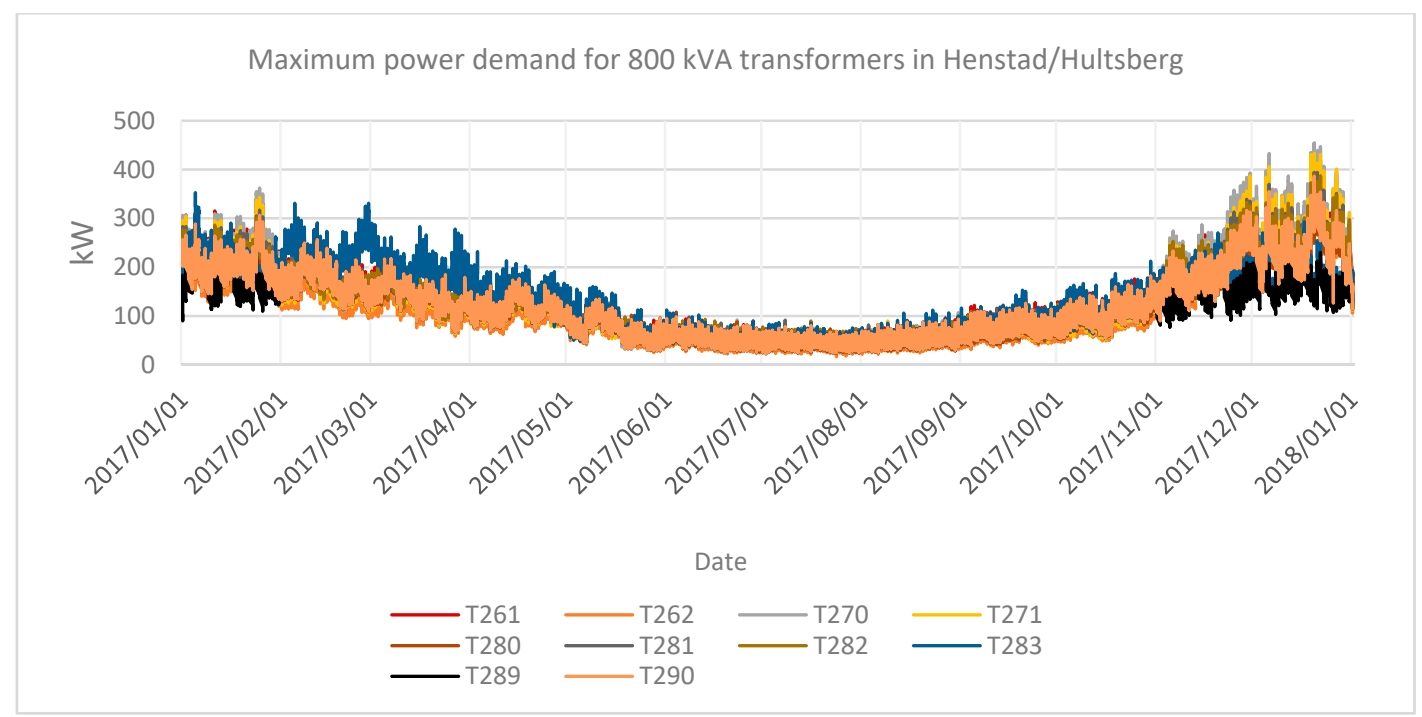

Figure 1. The power demand of $800 \mathrm{kVA}$ transformers.

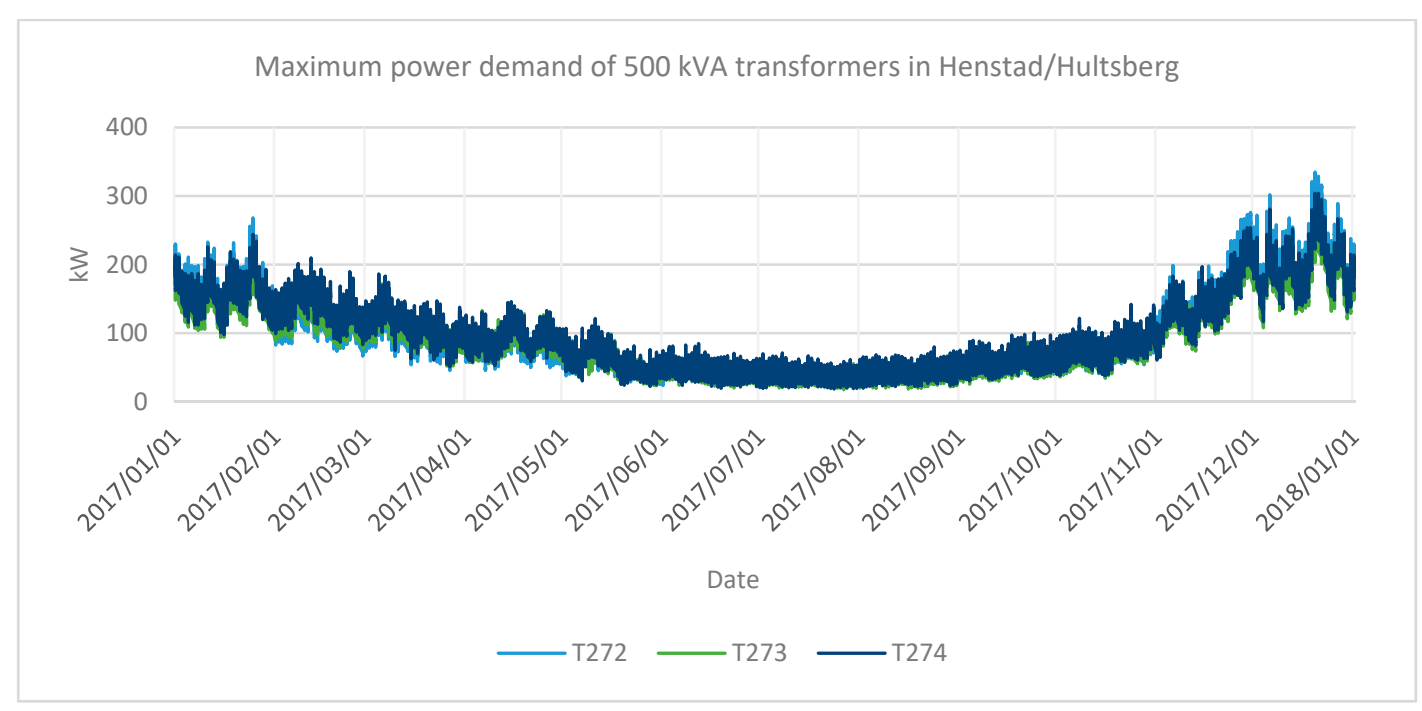

Figure 2. The power demand of $500 \mathrm{kVA}$ transformers.

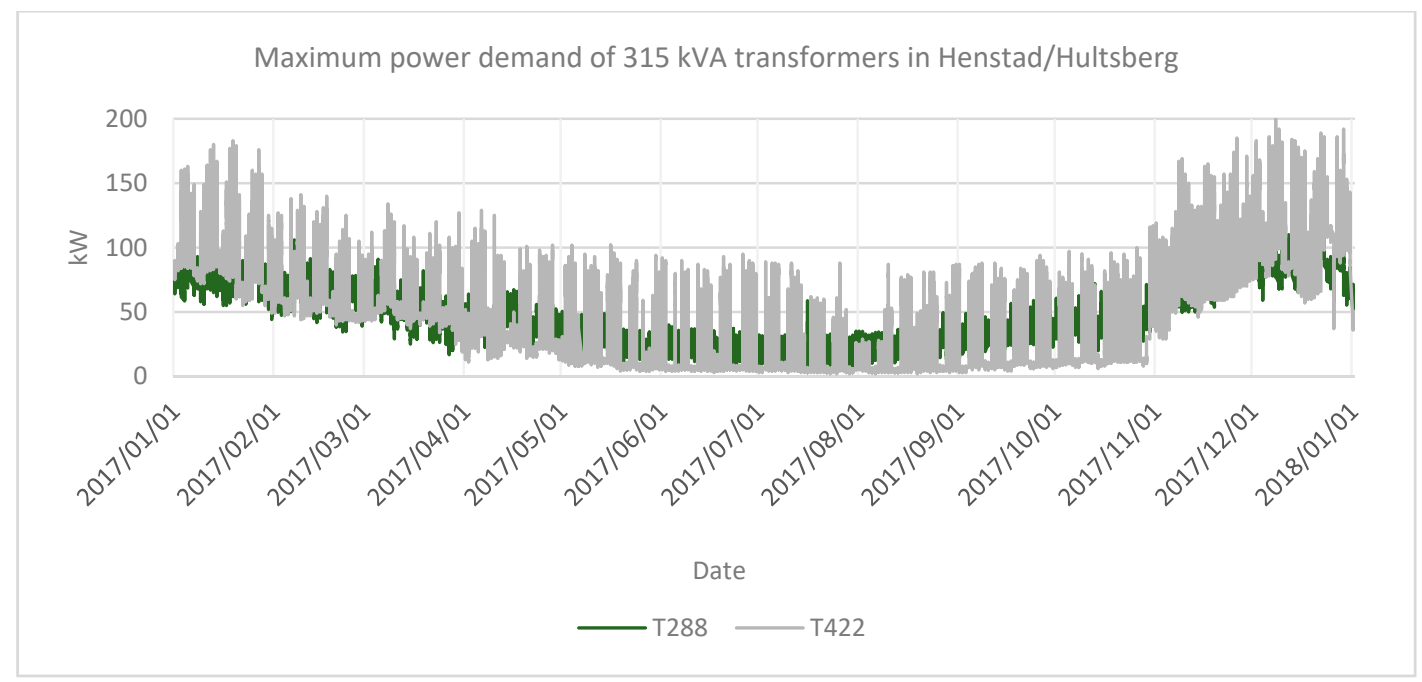

Figure 3. The power demand of $315 \mathrm{kVA}$ transformers. 
Table 2. Total power demand of the transformers.

\begin{tabular}{ccccc}
\hline Transformer & T261 & T262 & T273 & T422 \\
\hline Power demand GWh/year & 1.199749 & 0.964139 & 0.784951 & 0.463429 \\
Electricity demand GWh/year & 0.188939 & 0.289061 & 0.187890 & 0.463429 \\
Heating demand GWh/year & 1.010479 & 0.675078 & 0.597062 & 0.000000 \\
\hline
\end{tabular}

The power demand was calculated using Equation (A1) in the Appendix A. The available energy source via the transformer could not be determined since it was considered confidential and case sensitive data and since EnergyPLAN needs such an input, that power is considered as imported, and therefore, not included in the software. However, one can add this input as a source of energy in Microsoft Excel with varying values depending on the power requirement. When calculating balance for flexible demand, Equation (A2) was used and Equation (A3) was used when other energy sources were added to the system.

The charging profile was based primarily on a constant charge throughout the day with the intention of ensuring that the worst case is covered since it is not certain that all EVs are charged at a certain time of the day. "Worst case" is when all electric vehicles are charged while the regular household demands reach their maximum values.

Thereafter, a study was also made regarding how power demands change if charging occurs only on late nights and when most of the customer activities are on the lower level (i.e., between 22:00 and 06:00). This is illustrated in Figure 4.

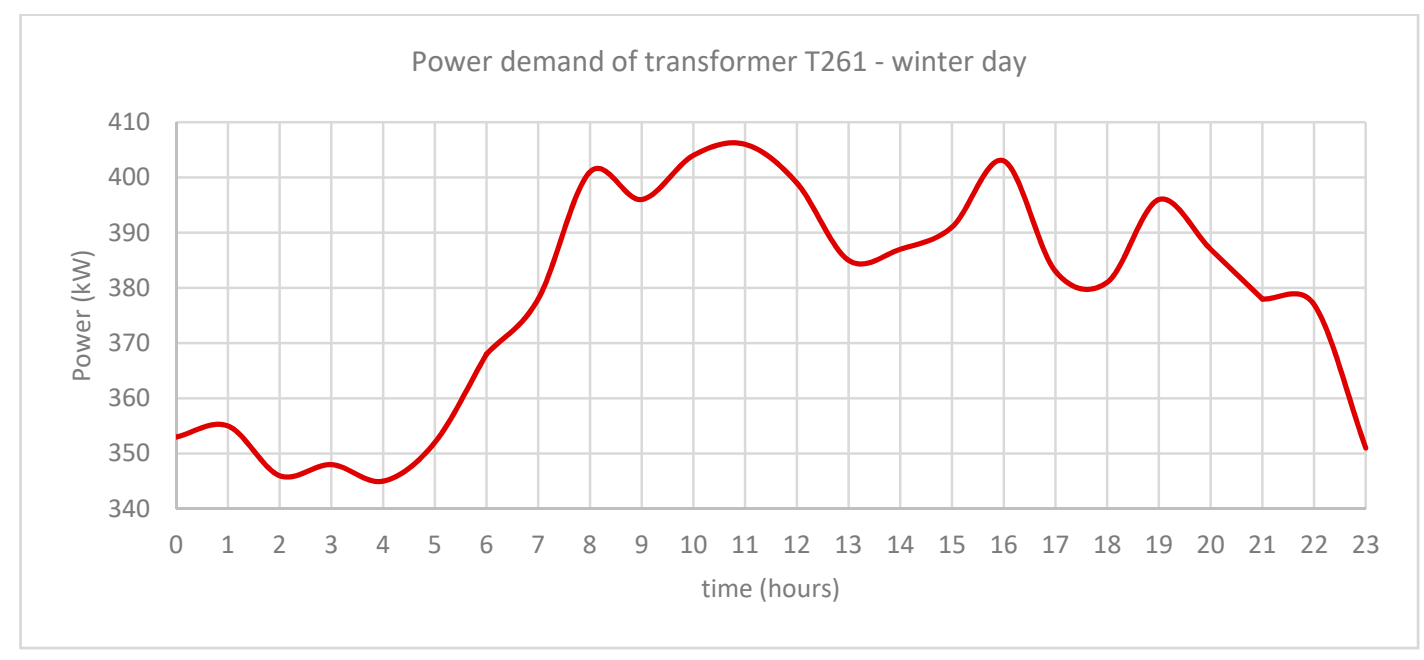

Figure 4. Power demand during the $24 \mathrm{~h}$.

According to the above assumptions, the following charge profiles were introduced, as shown in Figure 5. For the transformers T261, T262, and T273, the "Charging households" profile was used and, for the transformer T422, the "Charging industries" profile was used. For 'Charging industries,' it is assumed that staff work between 8:00 and 16:00.

The total power demand was calculated by Equation (A4) by multiplying the percentage of the distribution file by the number of EVs and the charging capacity. In this example, Equation (A5) was used to calculate the total batteries' capacity of the EVs and Equation (A6) was used to calculate the battery storage capacity. However, storage capacity has no impact on this study and has an assumed flat-rate value of approximately $80 \mathrm{kWh}$ per car. There were also tests with different amounts of EVs, both by changing the number of simultaneously charging cars and different amounts of cars available in the area.

At this point, investigations of what happens when solar cells are added to the network is made. Since the maximum permissible power of the transformer cannot exceed its peak power, the decision 
was made to limit the power of the solar cells by merely trying to cover the heating demand in the respective residence. This simulates that the input electricity from the solar cells only supplies the house with electricity and is not supplied into the power network. The solar panel's household heating supply was calculated by using Equation (A9). The data in Figure 6 shows the peak solar hours in Karlstad collected from the database STRÅNG [19] and the resulting balance was calculated using Equation (A8).

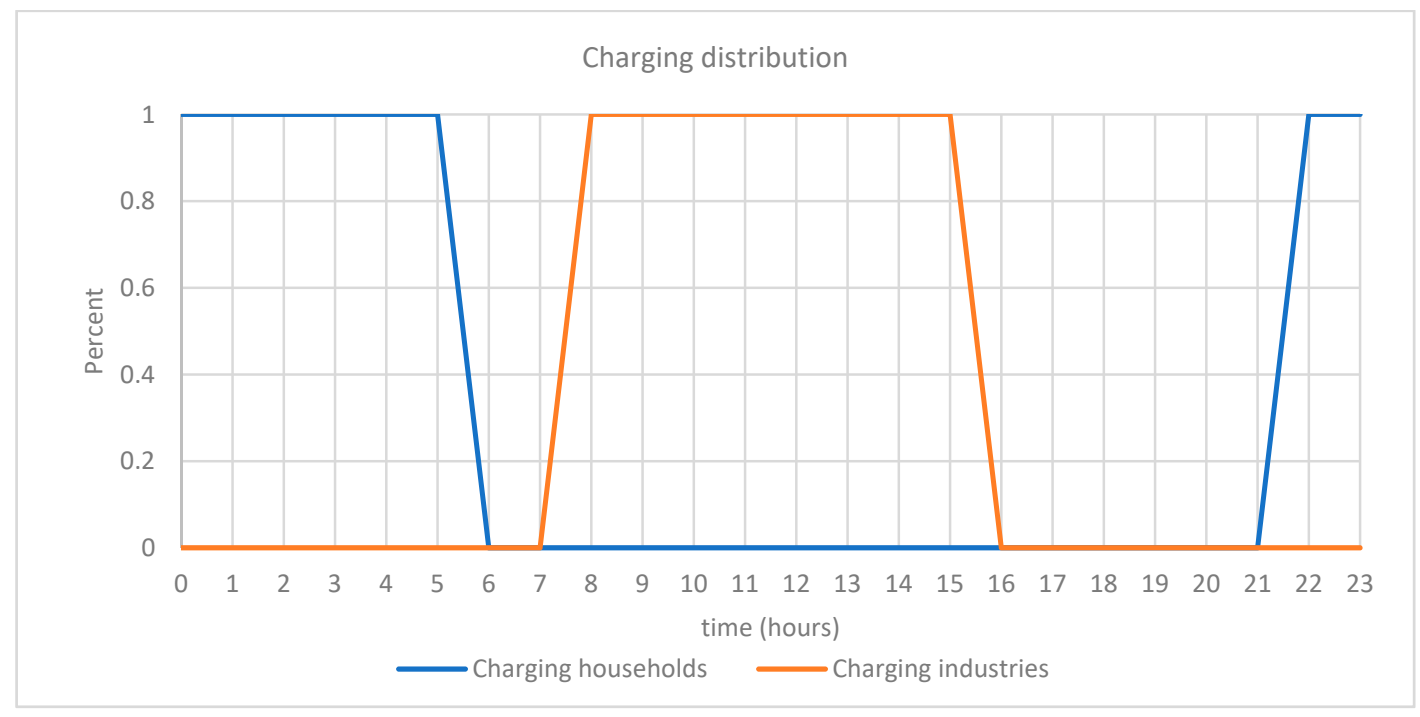

Figure 5. Assumed profiles.

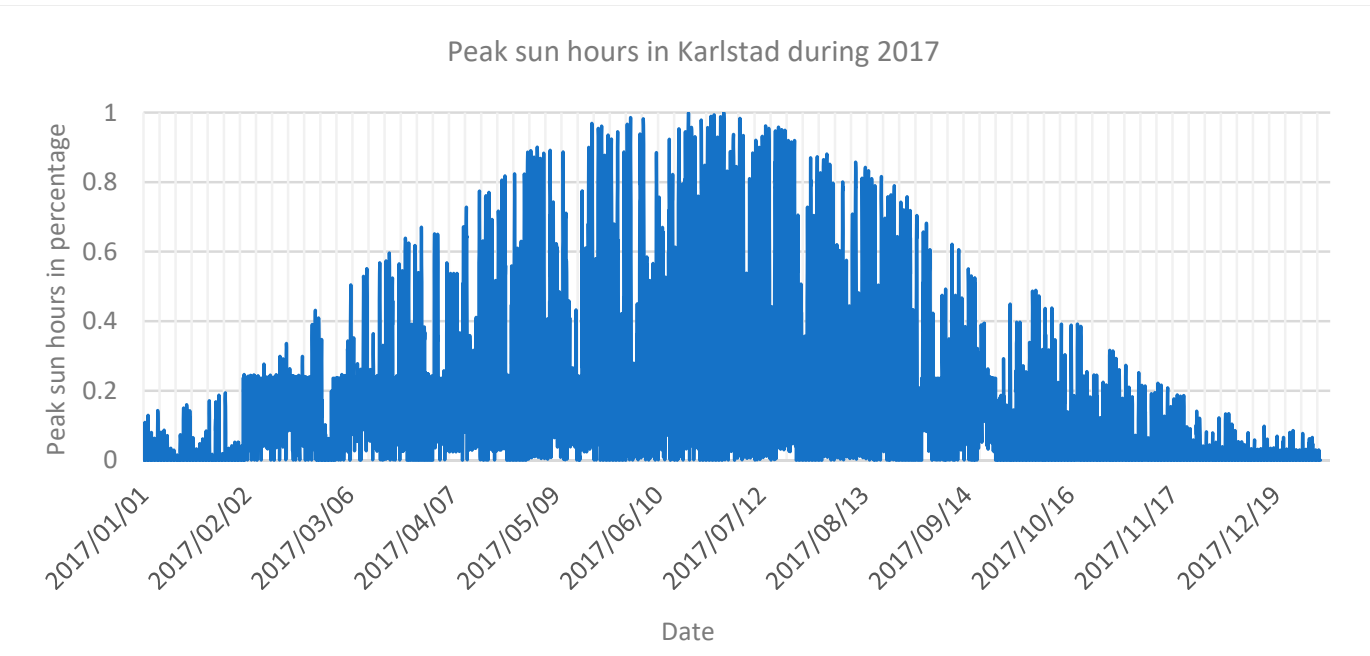

Figure 6. Peak sun hours in Karlstad during 2017 [19].

In order to use more of the available electricity during EVs charging, the electric heating was completely replaced by district heating to investigate whether it was possible to reduce the overall power demand via the transformer. The total energy supply was calculated, according to Equation (A10), and the balance was then calculated according to Equation (A8).

\section{Results}

In order to investigate several strategies toward a 100\% RES, under high penetration of EVs, and in the presence of different sources such as PVs, district heating, and ESD, four future scenarios of grid investments have been conducted. The parameters that configure the scenarios are: (i) the number 
of grid connected EVs, (ii) the level of charging rate, (iii) the charging profile, (iv) the flexible demand, and (v) the district heating versus heating using electrical units. The four scenarios are presented next.

The number of EVs was determined by using Karlstad Municipality's parking standard [20]. According to the parking standard, the number of cars per transformer are for T261 and T262 about 80 cars, T273 about 60 cars, and for T422, which is located at an industrial area, with about 40 cars. To cover more potential EVs for future needs, calculations are also made at \pm 20 cars per transformer.

Regarding EVs charging, several solutions could be applied, according to ABB [21]. ABB's "Mode 3 type 2" charging box [21], charging sizes can range from $2.3 \mathrm{~kW}$ (equivalent to single phase $230 \mathrm{~V}$ and $10 \mathrm{~A}$ fuse) up to possibly about $22 \mathrm{~kW}$ at home charging (corresponding to three-phase $400 \mathrm{~V}$ and 32 A fuse). The latter is, however, much less common. Three-phase charging maximizes charging power without the need to upgrade the main fuse and also allows for the distribution of the load on the phases. The most common charging sizes in Sweden are currently single-phase $2.3 \mathrm{~kW}$ and $3.7 \mathrm{~kW}$, and, sometimes, three-phase $6.9 \mathrm{~kW}$ and $11 \mathrm{~kW}$ in residential areas, since these only require a fuse of 10 and $16 \mathrm{~A}$, respectively. Since upgrading to an even bigger fuse is expensive and is not always desirable, most of the electric vehicles are charging at night when there is no need for faster charging.

Electric vehicle demands were added as either 'Dump Charge' or 'Smart Charge.' Dump Charge means that charging time is defined by the user through a distribution file and that the EV is constantly charged during that time. Smart Charge means that the EVs either are not charged constantly (partial charging) or that the EVs will save electricity by using part of the electricity stored in their batteries, which can then be used to reduce the surplus of electricity produced from renewable energy sources. Thus, the amount of electricity produced can be reduced, so the overload of the grid is avoided [22].

\subsection{Scenario 1 Parameters: Number of Electric Vehicles—Charging Rate-Charging Profile}

According to the first scenario, the impact of the integration of EVs is investigated with the following parameters analyzed: the number of grid-connected vehicles, the level of charging rate, and the charging profile. The maximum power differences seen in Tables 3 and 4 are the maximum power consumption after available power have been subtracted via the transformers.

Table 3. Maximum power balance 3.7, 6.9, or $11 \mathrm{~kW}$ power-constant charging.

\begin{tabular}{cccc}
\hline T261 & Max Difference & T262 & Max Difference \\
\hline Balance excluding EVs & $0 \mathrm{~kW}$ & Balance excluding EVs & $0 \mathrm{~kW}$ \\
Balance 60-3.7 & $-30 \mathrm{~kW}$ & Balance 60-3.7 & $0 \mathrm{~kW}$ \\
Balance 60-6.9 & $-22 \mathrm{~kW}$ & Balance 60-6.9 & $0 \mathrm{~kW}$ \\
Balance 60-11 & $-468 \mathrm{~kW}$ & Balance 60-11 & $-104 \mathrm{~kW}$ \\
Balance 80-3.7 & $-104 \mathrm{~kW}$ & Balance 80-3.7 & $0 \mathrm{~kW}$ \\
Balance 80-6.9 & $-360 \mathrm{~kW}$ & Balance 80-6.9 & $0 \mathrm{~kW}$ \\
Balance 80-11 & $-688 \mathrm{~kW}$ & Balance 80-11 & $-324 \mathrm{~kW}$ \\
Balance 100-3.7 & $-178 \mathrm{~kW}$ & Balance 100-3.7 & $0 \mathrm{~kW}$ \\
Balance 100-6.9 & $-498 \mathrm{~kW}$ & Balance 100-6.9 & $-134 \mathrm{~kW}$ \\
Balance 100-11 & $-908 \mathrm{~kW}$ & Balance 100-11 & $-544 \mathrm{~kW}$ \\
\hline T273 & Max Difference & T422 & Max Difference \\
\hline Balance excluding EVs & $0 \mathrm{~kW}$ & Balance excluding EVs & $0 \mathrm{~kW}$ \\
Balance 40-3.7 & $-35 \mathrm{~kW}$ & Balance 20-3.7 & $-22 \mathrm{~kW}$ \\
Balance 40-6.9 & $-163 \mathrm{~kW}$ & Balance 20-6.9 & $-86 \mathrm{~kW}$ \\
Balance 40-11 & $-327 \mathrm{~kW}$ & Balance 20-11 & $-168 \mathrm{~kW}$ \\
Balance 60-3.7 & $-109 \mathrm{~kW}$ & Balance 40-3.7 & $-96 \mathrm{~kW}$ \\
Balance 60-6.9 & $-301 \mathrm{~kW}$ & Balance 40-6.9 & $-224 \mathrm{~kW}$ \\
Balance 60-11 & $-547 \mathrm{~kW}$ & Balance 40-11 & $-388 \mathrm{~kW}$ \\
Balance 80-3.7 & $-183 \mathrm{~kW}$ & Balance 60-3.7 & $-170 \mathrm{~kW}$ \\
Balance 80-6.9 & $-439 \mathrm{~kW}$ & Balance 60-6.9 & $-362 \mathrm{~kW}$ \\
Balance 80-11 & $-767 \mathrm{~kW}$ & Balance 60-11 & $-608 \mathrm{~kW}$ \\
\hline
\end{tabular}


Table 4. Maximum power balance 3.7, 6.9, or $11 \mathrm{~kW}$ night-time charging.

\begin{tabular}{cccc}
\hline T261 & Max Difference & T262 & Max Difference \\
\hline Balance excluding EVs & $0 \mathrm{~kW}$ & Balance excluding EVs & $0 \mathrm{~kW}$ \\
Balance 60-3.7 & $0 \mathrm{~kW}$ & Balance 60-3.7 & $0 \mathrm{~kW}$ \\
Balance 60-6.9 & $-163 \mathrm{~kW}$ & Balance 60-6.9 & $-60 \mathrm{~kW}$ \\
Balance 60-11 & $-402 \mathrm{~kW}$ & Balance 60-11 & $-303 \mathrm{~kW}$ \\
Balance 80-3.7 & $-55 \mathrm{~kW}$ & Balance 80-3.7 & $0 \mathrm{~kW}$ \\
Balance 80-6.9 & $-299 \mathrm{~kW}$ & Balance 80-6.9 & $-197 \mathrm{~kW}$ \\
Balance 80-11 & $-612 \mathrm{~kW}$ & Balance 80-11 & $-518 \mathrm{~kW}$ \\
Balance 100-3.7 & $-125 \mathrm{~kW}$ & Balance 100-3.7 & $-22 \mathrm{~kW}$ \\
Balance 100-6.9 & $-424 \mathrm{~kW}$ & Balance 100-6.9 & $-98 \mathrm{~kW}$ \\
Balance 100-11 & $-822 \mathrm{~kW}$ & Balance 100-11 & $-509 \mathrm{~kW}$ \\
\hline T273 & Max Difference & T422 & Max Difference \\
\hline Balance excluding EVs & $0 \mathrm{~kW}$ & Balance excluding EVs & $0 \mathrm{~kW}$ \\
Balance 40-3.7 & $0 \mathrm{~kW}$ & Balance 20-3.7 & $-37 \mathrm{~kW}$ \\
Balance 40-6.9 & $-119 \mathrm{~kW}$ & Balance 20-6.9 & $-186 \mathrm{~kW}$ \\
Balance 40-11 & $-279 \mathrm{~kW}$ & Balance 20-11 & $-213 \mathrm{~kW}$ \\
Balance 60-3.7 & $-66 \mathrm{~kW}$ & Balance 40-3.7 & $-126 \mathrm{~kW}$ \\
Balance 60-6.9 & $-250 \mathrm{~kW}$ & Balance 40-6.9 & $-281 \mathrm{~kW}$ \\
Balance 60-11 & $-494 \mathrm{~kW}$ & Balance 40-11 & $-488 \mathrm{~kW}$ \\
Balance 80-3.7 & $-138 \mathrm{~kW}$ & Balance 60-3.7 & $-216 \mathrm{~kW}$ \\
Balance 80-6.9 & $-388 \mathrm{~kW}$ & Balance 60-6.9 & $-454 \mathrm{~kW}$ \\
Balance 80-11 & $-709 \mathrm{~kW}$ & Balance 60-11 & $-771 \mathrm{~kW}$ \\
\hline
\end{tabular}

Table 3 presents the maximum power balance with respect to the number of EVs under power-constant charging of 3.7, 6.9, and $11 \mathrm{~kW}$. Table 4 shows how the power demands change when charging occurs only at night and presents the maximum power balance with respect to the number of EVs under night-time charging of 3.7, 6.9, and $11 \mathrm{~kW}$. Most of the transformers can handle a smaller number of one-phase charged vehicles on a 16 A fuse. However, when customers want to have faster charging, the situation becomes complex because the maximum power difference increases. In particular, in cases where maximum penetration of EVs is inserted in combination with 6.9 and $11 \mathrm{~kW}$ charging rates, it seems unrealistic to expect a stable RES because the power balance is comparable to the transformer ratings. As such, either the transformers need to be replaced or solutions that are more flexible need to be examined.

\subsection{Scenario 2 Parameters: Number of Electric Vehicles_Charging Rate-Flexible Demand}

In the second scenario, the impact of different levels of flexible demand is investigated in relation to the number of grid-connected EVs and the charging rate. The effect of flexible demand on transformers T261, T262, T273, and T422 are shown in the Tables 5-8, respectively. In Table 4, the case T261 with 60 cars at $6.9 \mathrm{~kW}$ presents a maximum difference of $163 \mathrm{~kW}$ while, in Table 5, the same case T261 with 60 cars at $6.9 \mathrm{~kW}$ having flexible demand $50 \%$ presents a maximum difference of $50 \mathrm{~kW}$. In Table 4 , the case T273 with 60 cars at $3.7 \mathrm{~kW}$ presents a maximum difference of $66 \mathrm{~kW}$ while, in Table 7 , the same case T273 with 60 cars at $3.7 \mathrm{~kW}$ and with flexible demand of $50 \%$ presents a zero-maximum difference. Similar conclusions can be derived by controlling all cases where, in some cases, a lot of flexibility is needed to notice any effect. The results demonstrate that flexible demand can substantially reduce power consumption. 
Table 5. Effect of flexible demand for Transformer T261.

\begin{tabular}{cccccc}
\hline T261 & Max Difference & Max 10\% & Max 20\% & Max 30\% & Max 50\% \\
\hline Balance excluding EVs & $0 \mathrm{~kW}$ & $0 \mathrm{~kW}$ & $0 \mathrm{~kW}$ & $0 \mathrm{~kW}$ & $0 \mathrm{~kW}$ \\
Balance 60-3.7 & $0 \mathrm{~kW}$ & $0 \mathrm{~kW}$ & $0 \mathrm{~kW}$ & $0 \mathrm{~kW}$ & $0 \mathrm{~kW}$ \\
Balance 60-6.9 & $-186 \mathrm{~kW}$ & $-159 \mathrm{~kW}$ & $-134 \mathrm{~kW}$ & $-106 \mathrm{~kW}$ & $-50 \mathrm{~kW}$ \\
Balance 60-11 & $-432 \mathrm{~kW}$ & $-366 \mathrm{~kW}$ & $-300 \mathrm{~kW}$ & $-234 \mathrm{~kW}$ & $-126 \mathrm{~kW}$ \\
Balance 80-3.7 & $-68 \mathrm{~kW}$ & $-48 \mathrm{~kW}$ & $-32 \mathrm{~kW}$ & $-11 \mathrm{~kW}$ & $0 \mathrm{~kW}$ \\
Balance 80-6.9 & $-324 \mathrm{~kW}$ & $-269 \mathrm{~kW}$ & $-214 \mathrm{~kW}$ & $-158 \mathrm{~kW}$ & $-65 \mathrm{~kW}$ \\
Balance 80-11 & $-652 \mathrm{~kW}$ & $-572 \mathrm{~kW}$ & $-484 \mathrm{~kW}$ & $-396 \mathrm{~kW}$ & $-265 \mathrm{~kW}$ \\
Balance 100-3.7 & $-142 \mathrm{~kW}$ & $-113 \mathrm{~kW}$ & $-76 \mathrm{~kW}$ & $-39 \mathrm{~kW}$ & $0 \mathrm{~kW}$ \\
Balance 100-6.9 & $-462 \mathrm{~kW}$ & $-393 \mathrm{~kW}$ & $-324 \mathrm{~kW}$ & $-255 \mathrm{~kW}$ & $-144 \mathrm{~kW}$ \\
Balance 100-11 T261 & $-871 \mathrm{~kW}$ & $-777 \mathrm{~kW}$ & $-667 \mathrm{~kW}$ & $-557 \mathrm{~kW}$ & $-403 \mathrm{~kW}$ \\
\hline
\end{tabular}

Table 6. Effect of flexible demand for Transformer T262.

\begin{tabular}{cccccc}
\hline T262 & Max Difference & Max 10\% & Max 20\% & Max 30\% & Max 50\% \\
\hline Balance excluding EVs & $0 \mathrm{~kW}$ & $0 \mathrm{~kW}$ & $0 \mathrm{~kW}$ & $0 \mathrm{~kW}$ & $0 \mathrm{~kW}$ \\
Balance 60-3.7 & $0 \mathrm{~kW}$ & $0 \mathrm{~kW}$ & $0 \mathrm{~kW}$ & $0 \mathrm{~kW}$ & $0 \mathrm{~kW}$ \\
Balance 60-6.9 & $-83 \mathrm{~kW}$ & $-55 \mathrm{~kW}$ & $-24 \mathrm{~kW}$ & $0 \mathrm{~kW}$ & $0 \mathrm{~kW}$ \\
Balance 60-11 & $-329 \mathrm{~kW}$ & $-284 \mathrm{~kW}$ & $-237 \mathrm{~kW}$ & $-193 \mathrm{~kW}$ & $-105 \mathrm{~kW}$ \\
Balance 80-3.7 & $0 \mathrm{~kW}$ & $0 \mathrm{~kW}$ & $0 \mathrm{~kW}$ & $0 \mathrm{~kW}$ & $0 \mathrm{~kW}$ \\
Balance 80-6.9 & $-221 \mathrm{~kW}$ & $-183 \mathrm{~kW}$ & $-144 \mathrm{~kW}$ & $-107 \mathrm{~kW}$ & $-33 \mathrm{~kW}$ \\
Balance 80-11 & $-549 \mathrm{~kW}$ & $-489 \mathrm{~kW}$ & $-428 \mathrm{~kW}$ & $-369 \mathrm{~kW}$ & $-252 \mathrm{~kW}$ \\
Balance 100-3.7 & $-39 \mathrm{~kW}$ & $-13 \mathrm{~kW}$ & $0 \mathrm{~kW}$ & $0 \mathrm{~kW}$ & $0 \mathrm{~kW}$ \\
Balance 100-6.9 & $-359 \mathrm{~kW}$ & $-312 \mathrm{~kW}$ & $-263 \mathrm{~kW}$ & $-217 \mathrm{~kW}$ & $-125 \mathrm{~kW}$ \\
Balance 100-11 & $-768 \mathrm{~kW}$ & $-694 \mathrm{~kW}$ & $-617 \mathrm{~kW}$ & $-544 \mathrm{~kW}$ & $-397 \mathrm{~kW}$ \\
\hline
\end{tabular}

Table 7. Effect of flexible demand for Transformer T273.

\begin{tabular}{cccccc}
\hline T273 & Max Difference & Max 10\% & Max 20\% & Max 30\% & Max 50\% \\
\hline Balance excluding EVs & $0 \mathrm{~kW}$ & $0 \mathrm{~kW}$ & $0 \mathrm{~kW}$ & $0 \mathrm{~kW}$ & $0 \mathrm{~kW}$ \\
Balance 40-3.7 & $0 \mathrm{~kW}$ & $0 \mathrm{~kW}$ & $0 \mathrm{~kW}$ & $0 \mathrm{~kW}$ & $0 \mathrm{~kW}$ \\
Balance 40-6.9 & $-125 \mathrm{~kW}$ & $-108 \mathrm{~kW}$ & $-89 \mathrm{~kW}$ & $-70 \mathrm{~kW}$ & $-34 \mathrm{~kW}$ \\
Balance 40-11 & $-289 \mathrm{~kW}$ & $-262 \mathrm{~kW}$ & $-231 \mathrm{~kW}$ & $-202 \mathrm{~kW}$ & $-143 \mathrm{~kW}$ \\
Balance 60-3.7 & $-71 \mathrm{~kW}$ & $-59 \mathrm{~kW}$ & $-42 \mathrm{~kW}$ & $-27 \mathrm{~kW}$ & $0 \mathrm{~kW}$ \\
Balance 60-6.9 & $-263 \mathrm{~kW}$ & $-238 \mathrm{~kW}$ & $-208 \mathrm{~kW}$ & $-181 \mathrm{~kW}$ & $-126 \mathrm{~kW}$ \\
Balance 60-11 & $-509 \mathrm{~kW}$ & $-467 \mathrm{~kW}$ & $-421 \mathrm{~kW}$ & $-378 \mathrm{~kW}$ & $-290 \mathrm{~kW}$ \\
Balance 80-3.7 & $-145 \mathrm{~kW}$ & $-127 \mathrm{~kW}$ & $-106 \mathrm{~kW}$ & $-86 \mathrm{~kW}$ & $-47 \mathrm{~kW}$ \\
Balance 80-6.9 & $-401 \mathrm{~kW}$ & $-367 \mathrm{~kW}$ & $-328 \mathrm{~kW}$ & $-291 \mathrm{~kW}$ & $-218 \mathrm{~kW}$ \\
Balance 80-11 & $-729 \mathrm{~kW}$ & $-673 \mathrm{~kW}$ & $-612 \mathrm{~kW}$ & $-554 \mathrm{~kW}$ & $-436 \mathrm{~kW}$ \\
\hline
\end{tabular}

Table 8. Effect of flexible demand for Transformer T422.

\begin{tabular}{cccccc}
\hline T422 & Max Difference & Max 10\% & Max 20\% & Max 30\% & Max 50\% \\
\hline Balance excluding EVs & $0 \mathrm{~kW}$ & $0 \mathrm{~kW}$ & $0 \mathrm{~kW}$ & $0 \mathrm{~kW}$ & $0 \mathrm{~kW}$ \\
Balance 20-3.7 & $-22 \mathrm{~kW}$ & $-15 \mathrm{~kW}$ & $-7 \mathrm{~kW}$ & $0 \mathrm{~kW}$ & $0 \mathrm{~kW}$ \\
Balance 20-6.9 & $-86 \mathrm{~kW}$ & $-72 \mathrm{~kW}$ & $-58 \mathrm{~kW}$ & $-45 \mathrm{~kW}$ & $-17 \mathrm{~kW}$ \\
Balance 20-11 & $-168 \mathrm{~kW}$ & $-146 \mathrm{~kW}$ & $-124 \mathrm{~kW}$ & $-102 \mathrm{~kW}$ & $-58 \mathrm{~kW}$ \\
Balance 40-3.7 & $-96 \mathrm{~kW}$ & $-81 \mathrm{~kW}$ & $-66 \mathrm{~kW}$ & $-52 \mathrm{~kW}$ & $-22 \mathrm{~kW}$ \\
Balance 40-6.9 & $-224 \mathrm{~kW}$ & $-196 \mathrm{~kW}$ & $-169 \mathrm{~kW}$ & $-141 \mathrm{~kW}$ & $-86 \mathrm{~kW}$ \\
Balance 40-11 & $-419 \mathrm{~kW}$ & $-344 \mathrm{~kW}$ & $-300 \mathrm{~kW}$ & $-256 \mathrm{~kW}$ & $-168 \mathrm{~kW}$ \\
Balance 60-3.7 & $-170 \mathrm{~kW}$ & $-148 \mathrm{~kW}$ & $-126 \mathrm{~kW}$ & $-103 \mathrm{~kW}$ & $-59 \mathrm{~kW}$ \\
Balance 60-6.9 & $-393 \mathrm{~kW}$ & $-321 \mathrm{~kW}$ & $-279 \mathrm{~kW}$ & $-238 \mathrm{~kW}$ & $-155 \mathrm{~kW}$ \\
Balance 60-11 & $-639 \mathrm{~kW}$ & $-542 \mathrm{~kW}$ & $-476 \mathrm{~kW}$ & $-410 \mathrm{~kW}$ & $-299 \mathrm{~kW}$ \\
\hline
\end{tabular}




\subsection{Scenario 3 Parameters: Number of Electric Vehicles—Charging Rate—Charging Profile—District Heating}

The third scenario presents the power balance when space-heating using electrical units is gradually replaced by district heating with involved parameters acting as the number of connected EVs, the charging rate, and the charging profile. The effect of having district heating on transformers T261, T262, and T273 are provided in Tables 9-14, with both a constant charge and charging at night, respectively.

Table 9. Replacement of electric heating by district heating for transformer T261—constant charging.

\begin{tabular}{cccccc}
\hline T261 & Max Difference & Max 90\% & Max 80\% & Max 70\% & Max 60\% \\
\hline Balance excluding EVs & $0 \mathrm{~kW}$ & $0 \mathrm{~kW}$ & $0 \mathrm{~kW}$ & $0 \mathrm{~kW}$ & $0 \mathrm{~kW}$ \\
Balance 60-3.7 & $0 \mathrm{~kW}$ & $0 \mathrm{~kW}$ & $0 \mathrm{~kW}$ & $0 \mathrm{~kW}$ & $0 \mathrm{~kW}$ \\
Balance 60-6.9 & $0 \mathrm{~kW}$ & $0 \mathrm{~kW}$ & $0 \mathrm{~kW}$ & $0 \mathrm{~kW}$ & $0 \mathrm{~kW}$ \\
Balance 60-11 & $-75 \mathrm{~kW}$ & $-9 \mathrm{~kW}$ & $0 \mathrm{~kW}$ & $0 \mathrm{~kW}$ & $0 \mathrm{~kW}$ \\
Balance 80-3.7 & $0 \mathrm{~kW}$ & $0 \mathrm{~kW}$ & $0 \mathrm{~kW}$ & $0 \mathrm{~kW}$ & $0 \mathrm{~kW}$ \\
Balance 80-6.9 & $0 \mathrm{~kW}$ & $0 \mathrm{~kW}$ & $0 \mathrm{~kW}$ & $0 \mathrm{~kW}$ & $0 \mathrm{~kW}$ \\
Balance 80-11 & $-295 \mathrm{~kW}$ & $-207 \mathrm{~kW}$ & $-119 \mathrm{~kW}$ & $-31 \mathrm{~kW}$ & $0 \mathrm{~kW}$ \\
Balance 100-3.7 & $0 \mathrm{~kW}$ & $0 \mathrm{~kW}$ & $0 \mathrm{~kW}$ & $0 \mathrm{~kW}$ & $0 \mathrm{~kW}$ \\
Balance 100-6.9 & $-99 \mathrm{~kW}$ & $-30 \mathrm{~kW}$ & $0 \mathrm{~kW}$ & $0 \mathrm{~kW}$ & $0 \mathrm{~kW}$ \\
Balance 100-11 & $-515 \mathrm{~kW}$ & $-405 \mathrm{~kW}$ & $-295 \mathrm{~kW}$ & $-185 \mathrm{~kW}$ & $-75 \mathrm{~kW}$ \\
\hline
\end{tabular}

Table 10. Replacement of electric heating by district heating for transformer T261-late night charging.

\begin{tabular}{cccccc}
\hline T261 & Max Difference & Max 90\% & Max 80\% & Max 70\% & Max 60\% \\
\hline Balance excluding EVs & $0 \mathrm{~kW}$ & $0 \mathrm{~kW}$ & $0 \mathrm{~kW}$ & $0 \mathrm{~kW}$ & $0 \mathrm{~kW}$ \\
Balance 60-3.7 & $0 \mathrm{~kW}$ & $0 \mathrm{~kW}$ & $0 \mathrm{~kW}$ & $0 \mathrm{~kW}$ & $0 \mathrm{~kW}$ \\
Balance 60-6.9 & $0 \mathrm{~kW}$ & $0 \mathrm{~kW}$ & $0 \mathrm{~kW}$ & $0 \mathrm{~kW}$ & $0 \mathrm{~kW}$ \\
Balance 60-11 & $-63 \mathrm{~kW}$ & $0 \mathrm{~kW}$ & $0 \mathrm{~kW}$ & $0 \mathrm{~kW}$ & $0 \mathrm{~kW}$ \\
Balance 80-3.7 & $0 \mathrm{~kW}$ & $0 \mathrm{~kW}$ & $0 \mathrm{~kW}$ & $0 \mathrm{~kW}$ & $0 \mathrm{~kW}$ \\
Balance 80-6.9 & $0 \mathrm{~kW}$ & $0 \mathrm{~kW}$ & $0 \mathrm{~kW}$ & $0 \mathrm{~kW}$ & $0 \mathrm{~kW}$ \\
Balance 80-11 & $-283 \mathrm{~kW}$ & $-195 \mathrm{~kW}$ & $-107 \mathrm{~kW}$ & $-4 \mathrm{~kW}$ & $0 \mathrm{~kW}$ \\
Balance 100-3.7 & $0 \mathrm{~kW}$ & $0 \mathrm{~kW}$ & $0 \mathrm{~kW}$ & $0 \mathrm{~kW}$ & $0 \mathrm{~kW}$ \\
Balance 100-6.9 & $-93 \mathrm{~kW}$ & $-24 \mathrm{~kW}$ & $0 \mathrm{~kW}$ & $0 \mathrm{~kW}$ & $0 \mathrm{~kW}$ \\
Balance 100-11 & $-502 \mathrm{~kW}$ & $-392 \mathrm{~kW}$ & $-282 \mathrm{~kW}$ & $-172 \mathrm{~kW}$ & $-62 \mathrm{~kW}$ \\
\hline
\end{tabular}

Table 11. Replacement of electric heating by district heating for transformer T262—constant charging.

\begin{tabular}{cccccc}
\hline T262 & Max Difference & Max 90\% & Max 80\% & Max 70\% & Max 60\% \\
\hline Balance excluding EVs & $0 \mathrm{~kW}$ & $0 \mathrm{~kW}$ & $0 \mathrm{~kW}$ & $0 \mathrm{~kW}$ & $0 \mathrm{~kW}$ \\
Balance 60-3.7 & $0 \mathrm{~kW}$ & $0 \mathrm{~kW}$ & $0 \mathrm{~kW}$ & $0 \mathrm{~kW}$ & $0 \mathrm{~kW}$ \\
Balance 60-6.9 & $0 \mathrm{~kW}$ & $0 \mathrm{~kW}$ & $0 \mathrm{~kW}$ & $0 \mathrm{~kW}$ & $0 \mathrm{~kW}$ \\
Balance 60-11 & $-104 \mathrm{~kW}$ & $-38 \mathrm{~kW}$ & $0 \mathrm{~kW}$ & $0 \mathrm{~kW}$ & $0 \mathrm{~kW}$ \\
Balance 80-3.7 & $0 \mathrm{~kW}$ & $0 \mathrm{~kW}$ & $0 \mathrm{~kW}$ & $0 \mathrm{~kW}$ & $0 \mathrm{~kW}$ \\
Balance 80-6.9 & $0 \mathrm{~kW}$ & $0 \mathrm{~kW}$ & $0 \mathrm{~kW}$ & $0 \mathrm{~kW}$ & $0 \mathrm{~kW}$ \\
Balance 80-11 & $-324 \mathrm{~kW}$ & $-236 \mathrm{~kW}$ & $-148 \mathrm{~kW}$ & $-60 \mathrm{~kW}$ & $0 \mathrm{~kW}$ \\
Balance 100-3.7 & $0 \mathrm{~kW}$ & $0 \mathrm{~kW}$ & $0 \mathrm{~kW}$ & $0 \mathrm{~kW}$ & $0 \mathrm{~kW}$ \\
Balance 100-6.9 & $-134 \mathrm{~kW}$ & $-65 \mathrm{~kW}$ & $0 \mathrm{~kW}$ & $0 \mathrm{~kW}$ & $0 \mathrm{~kW}$ \\
Balance 100-11 & $-544 \mathrm{~kW}$ & $-434 \mathrm{~kW}$ & $-324 \mathrm{~kW}$ & $-214 \mathrm{~kW}$ & $-104 \mathrm{~kW}$ \\
\hline
\end{tabular}

The case of T262 with 80 cars at $11 \mathrm{~kW}$ charging rate presents a power difference of $518 \mathrm{~kW}$ in Table 4 . When $50 \%$ flexible demand is inserted, the power difference drops down to $252 \mathrm{~kW}$ in Table 6 while, in the case of $60 \%$ of space-heating, it is based on electricity and the $40 \%$ is covered by district heating. The power difference is already zero even with constant charging in Table 11. The results clearly indicate that the power balance is successfully achieved in most of the cases. However, maximum EVs penetration per transformer having the highest rate of charge of $11 \mathrm{~kW}$ is not 
easily manageable because results have a high power unbalance. Overall, the late-night charging leads to better power balance.

Table 12. Replacement of electric heating by district heating for transformer T262-late night charging.

\begin{tabular}{cccccc}
\hline T262 & Max Difference & Max 90\% & Max 80\% & Max 70\% & Max 60\% \\
\hline Balance excluding EVs & $0 \mathrm{~kW}$ & $0 \mathrm{~kW}$ & $0 \mathrm{~kW}$ & $0 \mathrm{~kW}$ & $0 \mathrm{~kW}$ \\
Balance 60-3.7 & $0 \mathrm{~kW}$ & $0 \mathrm{~kW}$ & $0 \mathrm{~kW}$ & $0 \mathrm{~kW}$ & $0 \mathrm{~kW}$ \\
Balance 60-6.9 & $0 \mathrm{~kW}$ & $0 \mathrm{~kW}$ & $0 \mathrm{~kW}$ & $0 \mathrm{~kW}$ & $0 \mathrm{~kW}$ \\
Balance 60-11 & $-89 \mathrm{~kW}$ & $-23 \mathrm{~kW}$ & $0 \mathrm{~kW}$ & $0 \mathrm{~kW}$ & $0 \mathrm{~kW}$ \\
Balance 80-3.7 & $0 \mathrm{~kW}$ & $0 \mathrm{~kW}$ & $0 \mathrm{~kW}$ & $0 \mathrm{~kW}$ & $0 \mathrm{~kW}$ \\
Balance 80-6.9 & $0 \mathrm{~kW}$ & $0 \mathrm{~kW}$ & $0 \mathrm{~kW}$ & $0 \mathrm{~kW}$ & $0 \mathrm{~kW}$ \\
Balance 80-11 & $-309 \mathrm{~kW}$ & $-221 \mathrm{~kW}$ & $-133 \mathrm{~kW}$ & $-45 \mathrm{~kW}$ & $0 \mathrm{~kW}$ \\
Balance 100-3.7 & $0 \mathrm{~kW}$ & $0 \mathrm{~kW}$ & $0 \mathrm{~kW}$ & $0 \mathrm{~kW}$ & $0 \mathrm{~kW}$ \\
Balance 100-6.9 & $-119 \mathrm{~kW}$ & $-50 \mathrm{~kW}$ & $0 \mathrm{~kW}$ & $0 \mathrm{~kW}$ & $0 \mathrm{~kW}$ \\
Balance 100-11 & $-528 \mathrm{~kW}$ & $-418 \mathrm{~kW}$ & $-308 \mathrm{~kW}$ & $-198 \mathrm{~kW}$ & $-88 \mathrm{~kW}$ \\
\hline
\end{tabular}

Table 13. Replacement of electric heating by district heating for transformer T273—constant charging.

\begin{tabular}{cccccc}
\hline T273 & Max Difference & Max 90\% & Max 80\% & Max 70\% & Max 60\% \\
\hline Balance excluding EVs & $0 \mathrm{~kW}$ & $0 \mathrm{~kW}$ & $0 \mathrm{~kW}$ & $0 \mathrm{~kW}$ & $0 \mathrm{~kW}$ \\
Balance 40-3.7 & $0 \mathrm{~kW}$ & $0 \mathrm{~kW}$ & $0 \mathrm{~kW}$ & $0 \mathrm{~kW}$ & $0 \mathrm{~kW}$ \\
Balance 40-6.9 & $0 \mathrm{~kW}$ & $0 \mathrm{~kW}$ & $0 \mathrm{~kW}$ & $0 \mathrm{~kW}$ & $0 \mathrm{~kW}$ \\
Balance 40-11 & $-94 \mathrm{~kW}$ & $-50 \mathrm{~kW}$ & $-6 \mathrm{~kW}$ & $0 \mathrm{~kW}$ & $0 \mathrm{~kW}$ \\
Balance 60-3.7 & $0 \mathrm{~kW}$ & $0 \mathrm{~kW}$ & $0 \mathrm{~kW}$ & $0 \mathrm{~kW}$ & $0 \mathrm{~kW}$ \\
Balance 60-6.9 & $-68 \mathrm{~kW}$ & $-27 \mathrm{~kW}$ & $0 \mathrm{~kW}$ & $0 \mathrm{~kW}$ & $0 \mathrm{~kW}$ \\
Balance 60-11 & $-314 \mathrm{~kW}$ & $-248 \mathrm{~kW}$ & $-182 \mathrm{~kW}$ & $-116 \mathrm{~kW}$ & $-50 \mathrm{~kW}$ \\
Balance 80-3.7 & $0 \mathrm{~kW}$ & $0 \mathrm{~kW}$ & $0 \mathrm{~kW}$ & $0 \mathrm{~kW}$ & $0 \mathrm{~kW}$ \\
Balance 80-6.9 & $-206 \mathrm{~kW}$ & $-151 \mathrm{~kW}$ & $-96 \mathrm{~kW}$ & $-40 \mathrm{~kW}$ & $0 \mathrm{~kW}$ \\
Balance 80-11 & $-534 \mathrm{~kW}$ & $-446 \mathrm{~kW}$ & $-358 \mathrm{~kW}$ & $-270 \mathrm{~kW}$ & $-182 \mathrm{~kW}$ \\
\hline
\end{tabular}

Table 14. Replacement of electric heating by district heating for transformer T273-late night charging.

\begin{tabular}{cccccc}
\hline T273 & Max Difference & Max $\mathbf{9 0} \%$ & Max $80 \%$ & Max 70\% & Max $\mathbf{6 0} \%$ \\
\hline Balance excluding EVs & $0 \mathrm{~kW}$ & $0 \mathrm{~kW}$ & $0 \mathrm{~kW}$ & $0 \mathrm{~kW}$ & $0 \mathrm{~kW}$ \\
Balance 40-3.7 & $0 \mathrm{~kW}$ & $0 \mathrm{~kW}$ & $0 \mathrm{~kW}$ & $0 \mathrm{~kW}$ & $0 \mathrm{~kW}$ \\
Balance 40-6.9 & $0 \mathrm{~kW}$ & $0 \mathrm{~kW}$ & $0 \mathrm{~kW}$ & $0 \mathrm{~kW}$ & $0 \mathrm{~kW}$ \\
Balance 40-11 & $-85 \mathrm{~kW}$ & $-41 \mathrm{~kW}$ & $0 \mathrm{~kW}$ & $0 \mathrm{~kW}$ & $0 \mathrm{~kW}$ \\
Balance 60-3.7 & $0 \mathrm{~kW}$ & $0 \mathrm{~kW}$ & $0 \mathrm{~kW}$ & $0 \mathrm{~kW}$ & $0 \mathrm{~kW}$ \\
Balance 60-6.9 & $-59 \mathrm{~kW}$ & $-18 \mathrm{~kW}$ & $0 \mathrm{~kW}$ & $0 \mathrm{~kW}$ & $0 \mathrm{~kW}$ \\
Balance 60-11 & $-305 \mathrm{~kW}$ & $-239 \mathrm{~kW}$ & $-173 \mathrm{~kW}$ & $-107 \mathrm{~kW}$ & $-41 \mathrm{~kW}$ \\
Balance 80-3.7 & $0 \mathrm{~kW}$ & $0 \mathrm{~kW}$ & $0 \mathrm{~kW}$ & $0 \mathrm{~kW}$ & $0 \mathrm{~kW}$ \\
Balance 80-6.9 & $-197 \mathrm{~kW}$ & $-142 \mathrm{~kW}$ & $-87 \mathrm{~kW}$ & $-31 \mathrm{~kW}$ & $0 \mathrm{~kW}$ \\
Balance 80-11 & $-525 \mathrm{~kW}$ & $-437 \mathrm{~kW}$ & $-349 \mathrm{~kW}$ & $-261 \mathrm{~kW}$ & $-173 \mathrm{~kW}$ \\
\hline
\end{tabular}

\subsection{Scenario 4 Parameters: Number of Electric Vehicles_Charging Rate—Flexible Demand_District Heating}

In the fourth scenario, district heating replaces space-heating using electrical units, several levels of flexible demand are involved with parameters of the number of connected EVs and the charging rate. The effect of having several levels of flexible demand in the presence of district heating on transformers T261, T262, and T273 are provided in Tables 15-17, with charging at night, respectively. For example, the case of T262 with 80 cars at $11 \mathrm{~kW}$ charging rate and 50\% flexibility in Table 16 presents a power difference of $3 \mathrm{~kW}$. By comparing to the case T262 with 80 cars at an $11 \mathrm{~kW}$ charging rate and when $60 \%$ of space-heating is based on electricity and the $40 \%$ is covered by district heating in Table 12 , which presents a power difference of zero, one concludes that district heating could be more important than flexible demand. Similar conclusions reveal, by comparing the other cases and, hence, district 
heating in combination with flexible demand is considered as one of the most promising scenarios in this case study.

Table 15. Replacement of electric heating by district heating in the presence of flexible demand for transformer T261—Charging at night.

\begin{tabular}{cccccc}
\hline T261 & Max Difference & Max 10\% & Max 20\% & Max 30\% & Max 50\% \\
\hline Balance excluding EVs & $0 \mathrm{~kW}$ & $0 \mathrm{~kW}$ & $0 \mathrm{~kW}$ & $0 \mathrm{~kW}$ & $0 \mathrm{~kW}$ \\
Balance 60-3.7 & $0 \mathrm{~kW}$ & $0 \mathrm{~kW}$ & $0 \mathrm{~kW}$ & $0 \mathrm{~kW}$ & $0 \mathrm{~kW}$ \\
Balance 60-6.9 & $0 \mathrm{~kW}$ & $0 \mathrm{~kW}$ & $0 \mathrm{~kW}$ & $0 \mathrm{~kW}$ & $0 \mathrm{~kW}$ \\
Balance 60-11 & $-63 \mathrm{~kW}$ & $-8 \mathrm{~kW}$ & $0 \mathrm{~kW}$ & $0 \mathrm{~kW}$ & $0 \mathrm{~kW}$ \\
Balance 80-3.7 & $0 \mathrm{~kW}$ & $0 \mathrm{~kW}$ & $0 \mathrm{~kW}$ & $0 \mathrm{~kW}$ & $0 \mathrm{~kW}$ \\
Balance 80-6.9 & $0 \mathrm{~kW}$ & $0 \mathrm{~kW}$ & $0 \mathrm{~kW}$ & $0 \mathrm{~kW}$ & $0 \mathrm{~kW}$ \\
Balance 80-11 & $-283 \mathrm{~kW}$ & $-213 \mathrm{~kW}$ & $-151 \mathrm{~kW}$ & $-91 \mathrm{~kW}$ & $0 \mathrm{~kW}$ \\
Balance 100-3.7 & $0 \mathrm{~kW}$ & $0 \mathrm{~kW}$ & $0 \mathrm{~kW}$ & $0 \mathrm{~kW}$ & $0 \mathrm{~kW}$ \\
Balance 100-6.9 & $-93 \mathrm{~kW}$ & $-36 \mathrm{~kW}$ & $0 \mathrm{~kW}$ & $0 \mathrm{~kW}$ & $0 \mathrm{~kW}$ \\
Balance 100-11 & $-502 \mathrm{~kW}$ & $-430 \mathrm{~kW}$ & $-357 \mathrm{~kW}$ & $-286 \mathrm{~kW}$ & $-139 \mathrm{~kW}$ \\
\hline
\end{tabular}

Table 16. Replacement of electric heating by district heating in the presence of flexible demand for transformer T262-Charging at night.

\begin{tabular}{cccccc}
\hline T262 & Max Difference & Max 10\% & Max 20\% & Max 30\% & Max 50\% \\
\hline Balance excluding EVs & $0 \mathrm{~kW}$ & $0 \mathrm{~kW}$ & $0 \mathrm{~kW}$ & $0 \mathrm{~kW}$ & $0 \mathrm{~kW}$ \\
Balance 60-3.7 & $0 \mathrm{~kW}$ & $0 \mathrm{~kW}$ & $0 \mathrm{~kW}$ & $0 \mathrm{~kW}$ & $0 \mathrm{~kW}$ \\
Balance 60-6.9 & $0 \mathrm{~kW}$ & $0 \mathrm{~kW}$ & $0 \mathrm{~kW}$ & $0 \mathrm{~kW}$ & $0 \mathrm{~kW}$ \\
Balance 60-11 & $-89 \mathrm{~kW}$ & $-42 \mathrm{~kW}$ & $0 \mathrm{~kW}$ & $0 \mathrm{~kW}$ & $0 \mathrm{~kW}$ \\
Balance 80-3.7 & $0 \mathrm{~kW}$ & $0 \mathrm{~kW}$ & $0 \mathrm{~kW}$ & $0 \mathrm{~kW}$ & $0 \mathrm{~kW}$ \\
Balance 80-6.9 & $0 \mathrm{~kW}$ & $0 \mathrm{~kW}$ & $0 \mathrm{~kW}$ & $0 \mathrm{~kW}$ & $0 \mathrm{~kW}$ \\
Balance 80-11 & $-309 \mathrm{~kW}$ & $-247 \mathrm{~kW}$ & $-185 \mathrm{~kW}$ & $-120 \mathrm{~kW}$ & $-3 \mathrm{~kW}$ \\
Balance 100-3.7 & $0 \mathrm{~kW}$ & $0 \mathrm{~kW}$ & $0 \mathrm{~kW}$ & $0 \mathrm{~kW}$ & $0 \mathrm{~kW}$ \\
Balance 100-6.9 & $-119 \mathrm{~kW}$ & $-70 \mathrm{~kW}$ & $-20 \mathrm{~kW}$ & $0 \mathrm{~kW}$ & $0 \mathrm{~kW}$ \\
Balance 100-11 & $-528 \mathrm{~kW}$ & $-451 \mathrm{~kW}$ & $-374 \mathrm{~kW}$ & $-295 \mathrm{~kW}$ & $-148 \mathrm{~kW}$ \\
\hline
\end{tabular}

Table 17. Replacement of electric heating by district heating in the presence of flexible demand for transformer T273-Charging at night.

\begin{tabular}{cccccc}
\hline T273 & Max Difference & Max 90\% & Max 80\% & Max 70\% & Max 60\% \\
\hline Balance excluding EVs & $0 \mathrm{~kW}$ & $0 \mathrm{~kW}$ & $0 \mathrm{~kW}$ & $0 \mathrm{~kW}$ & $0 \mathrm{~kW}$ \\
Balance 40-3.7 & $0 \mathrm{~kW}$ & $0 \mathrm{~kW}$ & $0 \mathrm{~kW}$ & $0 \mathrm{~kW}$ & $0 \mathrm{~kW}$ \\
Balance 40-6.9 & $0 \mathrm{~kW}$ & $0 \mathrm{~kW}$ & $0 \mathrm{~kW}$ & $0 \mathrm{~kW}$ & $0 \mathrm{~kW}$ \\
Balance 40-11 & $-85 \mathrm{~kW}$ & $-53 \mathrm{~kW}$ & $-22 \mathrm{~kW}$ & $0 \mathrm{~kW}$ & $0 \mathrm{~kW}$ \\
Balance 60-3.7 & $0 \mathrm{~kW}$ & $0 \mathrm{~kW}$ & $0 \mathrm{~kW}$ & $0 \mathrm{~kW}$ & $0 \mathrm{~kW}$ \\
Balance 60-6.9 & $-59 \mathrm{~kW}$ & $-30 \mathrm{~kW}$ & $0 \mathrm{~kW}$ & $0 \mathrm{~kW}$ & $0 \mathrm{~kW}$ \\
Balance 60-11 & $-305 \mathrm{~kW}$ & $-259 \mathrm{~kW}$ & $-212 \mathrm{~kW}$ & $-164 \mathrm{~kW}$ & $-76 \mathrm{~kW}$ \\
Balance 80-3.7 & $0 \mathrm{~kW}$ & $0 \mathrm{~kW}$ & $0 \mathrm{~kW}$ & $0 \mathrm{~kW}$ & $0 \mathrm{~kW}$ \\
Balance 80-6.9 & $-197 \mathrm{~kW}$ & $-158 \mathrm{~kW}$ & $-119 \mathrm{~kW}$ & $-77 \mathrm{~kW}$ & $-4 \mathrm{~kW}$ \\
Balance 80-11 & $-525 \mathrm{~kW}$ & $-464 \mathrm{~kW}$ & $-403 \mathrm{~kW}$ & $-340 \mathrm{~kW}$ & $-223 \mathrm{~kW}$ \\
\hline
\end{tabular}

\subsection{Analysis of the Results}

The integration of electric vehicles to the distribution network is a complicated task and the results of this study on a real system clearly indicate that the EV owners will share an active role during the integration phase. Moreover, the customers' behavior will ensure the viability of the integration solution in each particular case. As was expected, when the customers choose to charge with higher charging rates, analogously higher power peak demands are observed. In such a case, a deterring measure is always based on higher rates per $\mathrm{kWh}$. However, there are limitations either because there 
are no established business models for such cases or there are limitations on the establishment of high pricing rates because electricity is considered a social necessity.

Flexible demand through power management is a promising option to reduce overall power consumption. However, it is required that the customers agree that their electrical consumption is managed in such a manner. The usage of photovoltaics cannot analogously mitigate the problem because power production takes place during daytime while residential EVs charging takes place mostly after midnight. In such a concept, the utilization of batteries or other storage methods mitigates the problem. On the contrary, the nightly charging could be seen as peak shaving and load shifting from a residential load profile perspective.

A simple and feasible alternative is based on the usage of on-grid photovoltaic systems to charge storage units during the day. Thereafter, the energy management decision tree takes action and, when it finds an effective alternative to use the stored energy, the storage units discharge. However, this concept finds difficulties in Swedish applications during winter times. Suitable business models need to be developed between the distribution operators, the real estate companies, and the individual customers.

Another alternative is based on the replacement of the electrical consumption for space heating by district heating. In this way, practically all EVs per household could be charged with optional charging capacities between 3.7 and $11 \mathrm{~kW}$. Furthermore, it is up to the customers as to whether they want to invest in something that can be cheaper over the years or continue to use electrical units for space-heating. A substantial incentive is required to encourage the customers to change their space-heating, especially if almost all vehicles are going to be replaced by EVs in the future.

Lastly, there are cases where a grid upgrade is necessary. For example, regarding transformer T422, there is no other choice except to replace it, if several EVs pop up. At present, it can handle a maximum of 10-20 EVs that charge at the lowest charging rate because there is only about $50 \mathrm{~kW}$ electrical power available during the winter.

\section{Conclusions}

The charging levels that have been chosen to investigate were $3.7,6.9$, and $11 \mathrm{~kW}$. It was assumed that single-phase charging of $2.3 \mathrm{~kW}$ can be handled by all transformers, so it was not included in this study. Moreover, a charging level over $11 \mathrm{~kW}$ is not considered necessary at residential areas and, in addition, this charging level requires larger mains installations.

Regarding the scenarios presented in this work, regarding the pattern of EVs penetration into the electrical distribution grid, one can say that more investigation and realistic scenarios need to be examined in order to define the safe strategy for an optimal solution. This is because the insertion of new technologies and customers' needs into the electrical networks is related to several technological developments, such as on batteries, on cables, on local controllers, and energy on central energy management techniques on both a secondary and tertiary control level. In addition, the solid requirement for sustainable social development will strongly affect the landscape of the future energy systems. Regarding the electrification of the transportation sector, there will likely be an extended variation in the vehicle alternatives in the coming years. Consequently, it is not very clear how this particular market will affect these decisions in the future.

The proposed solution at this particular stage would be a combination of alternatives as those proposed and analyzed in this study. One of the most promising alternatives would be to replace the space-heating based on electric units by other heating methods, which are not dependent on electricity such as district heating. Moreover, utilization of methods for flexible demand offers attractive alternative, which, in combination with other grid investments like peak shaving or distributed storage, could be very effective.

Author Contributions: H.M. Investigation, S.B. Formal Analysis, S.L. Writing-Review \& Editing, and A.T. Supervision. Funding: This research received no external funding. 
Acknowledgments: The authors would like to acknowledge Karlstads El- och Stadsnät AB, Sweden for providing grid data and support.

Conflicts of Interest: The authors declare no conflict of interest.

\section{Abbreviations}

\begin{tabular}{|c|c|}
\hline Balance & The balance between the surplus and demand of produced heat \\
\hline CEEP & Critical excess electricity production \\
\hline $\mathrm{CHP}$ & Combined heat and power from power plants \\
\hline $\mathrm{C}_{\text {CHARGER }}$ & The grid connection's capacity \\
\hline$C_{V 2 G}$ & Total grid connection of the total electric vehicle fleet capacity per hour \\
\hline DHP & District heat and power \\
\hline District Heating Production & The power produced by district heating \\
\hline District Heating Demand & The total heat demand of connected customers \\
\hline EEP & Excess electrical production \\
\hline $\mathrm{EH}$ & District heating provided by electric boilers \\
\hline$e_{\mathrm{INV}}$ & Electricity production (inverters) \\
\hline Elec. Demand & The electricity demand \\
\hline Electrolyser & Electrolyser power consumption \\
\hline ELT & District heating from surplus heat produced by electrolysers \\
\hline $\operatorname{Exp}$ & Electricity available for export \\
\hline Flex. and Transp. & Flexible and transport demand \\
\hline Geothermal & Geothermal power production \\
\hline Gr. 1 & Group 1 (representing district heating without combined heat and power) \\
\hline Gr. 2 & $\begin{array}{l}\text { Group } 2 \text { (representing district heating with small combined heat and } \\
\text { power plants) }\end{array}$ \\
\hline Gr. 3 & $\begin{array}{l}\text { Group } 3 \text { (representing district heating with large combined heat and } \\
\text { power plants) }\end{array}$ \\
\hline $\mathrm{HDH} 3$ & Heat demand in district heating group 3 \\
\hline $\mathrm{HP}$ & District heating from heat pumps \\
\hline Hydro & Electricity production via hydro power \\
\hline Hydro Pump & The hydro pump's power demand \\
\hline $\operatorname{Imp}$ & Import of electricity - the extra electricity needed to support the grid \\
\hline$n$ & Number of electric vehicles \\
\hline$n_{\mathrm{EV}}$ & Number of electric vehicles \\
\hline$n_{\text {household }}$ & Number of households \\
\hline$n_{\text {norm }}$ & Number of vehicles per household according to Karlstad's parking norm \\
\hline$P_{E V}$ & Total power demand when charging EV's \\
\hline Pdemand & Total power demand per hour \\
\hline PP & Electricity production via power plants \\
\hline $\mathrm{PPV} / \mathrm{h}$ & Power produced by solar panels per hour \\
\hline PPVtotal & Total amount of power desired from solar panels \\
\hline$P_{\text {supply }}$ & Total power supply per hour \\
\hline$P_{\text {total demand }}$ & The total annual power demand in the grid \\
\hline$P_{\text {total supply }}$ & The total annual power supply to the grid \\
\hline$P_{\text {transformer }}$ & Available power via the transformer per hour \\
\hline QDH3 & Heat production in district heating group 3 \\
\hline RES & Electricity production via renewable energy sources \\
\hline$\Sigma_{\text {demand } / h}$ & The total sum of the power demand per hour \\
\hline$\sum_{\text {hours }}$ & The sum of hours in 366 days \\
\hline Solar & District heating via solar panels \\
\hline StabLoad & The grid stability in $\%$ \\
\hline Storage & The amount of district heating stored in thermal storage systems \\
\hline
\end{tabular}


$S_{\mathrm{V} 2 \mathrm{G}}$

$T_{80 \%}$

Turbine

V2 $\mathrm{G}_{M A X}$

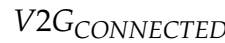

Waste CSHP

$\delta_{\mathrm{PV}}$

$\delta_{\mathrm{V} 2 \mathrm{G}}$

$\mu_{\mathrm{INV}}$

$\rho_{\mathrm{DH} 3}$
The total storage capacity of the EV batteries $80 \%$ of the available power through a transformer Electricity production via turbines

The maximum number of vehicles in traffic simultaneously in per cent

The maximum number of electric vehicles connected to the grid at the same time in per cent

District heating via waste combustion and from industries

Distribution of the solar panels' efficiency

Distribution the power demand of EV's

The efficiency of the connection between the batteries and the grid (inverter) Heat losses in district heating group 3

\section{Appendix A}

The total power consumption per year is given by the equation:

$$
P_{\text {total demand }}=\frac{\sum_{\text {power demand } / \text { year }}}{\sum_{\text {hours }}}
$$

The available transformer power is:

$$
P_{\text {transformer }}=\operatorname{IF}\left(P_{\text {demand }}>T_{80 \%} \text { THEN } P_{\text {transformer }}=T_{80 \%}, E L S E P_{\text {transformer }}=P_{\text {demand }}\right)
$$

and

$$
\begin{aligned}
P_{\text {transformer }}=\quad & \text { IF }\left(P_{\text {demand }}-P_{\text {supply }}>T_{80 \%}, \text { THEN } P_{\text {transformer }}\right. \\
& \left.=T_{80 \%}, E L S E P_{\text {transformer }}=P_{\text {demand }}-P_{\text {supply }}\right)
\end{aligned}
$$

The power demand of electric vehicles is provided by Reference [20] while charging electric vehicles:

$$
P_{E V}=n * \delta_{V 2 G} * C_{\text {charger }}
$$

Total capacity of the batteries of electric vehicles:

$$
C_{V 2 G}=C_{\text {charger }} * V 2 G_{\text {connected }} *\left(1-V 2 G_{\max }\right)+V 2 G_{\max } *\left(1-\frac{\delta_{V 2 G}}{\operatorname{Max}\left(\delta_{V 2 G}\right)}\right)
$$

The batteries' storage capacity:

$$
S_{V 2 G}=s_{V 2 G}-\frac{e_{i n v}}{\mu_{i n v}}
$$

The number of electric vehicles:

$$
n_{E V} \approx n_{\text {norm }} * n_{\text {households }}
$$

The balance of power:

$$
\text { Balance }=P_{\text {total demand }}-P_{\text {total supply }}
$$

The solar panels' supply to the grid by using Reference [20] and the solar panels' power supply per hour:

$$
P_{P V / h}=\delta_{P V} * P_{P V t o t a l}
$$

Power supply from district heating by using Reference [20] and the power supply per hour provided by district heating:

$$
H_{D H 3}=Q_{D H 3} *\left(1-\rho_{D H 3}\right)
$$

\section{References}

1. United Nations Treaty Collection Repository. Paris Agreement. 15 December 2015. Available online: https://treaties.un.org/ (accessed on 5 March 2019).

2. Intergovernmental Panel on Climate Change. Available online: https://www.ipcc.ch (accessed on 12 March 2018).

3. Markovic, F.; Lazarou, S.; Dagoumas, A. Energy and climate policy with the GCAM model: Assessing energy sources and technology options. Int. J. Renew. Energy Res. 2018, 8, 2299-2309. 
4. Morais, H.; Sousa, T.; Vale, Z.; Faria, P. Evaluation of the electric vehicle impact in the power demand curve in a smart grid environment. Energy Convers. Manag. 2014, 82, 268-282. [CrossRef]

5. Knezović, K.; Marinelli, M.; Zecchino, A.; Andersen, P.B.; Traeholt, C. Supporting involvement of electric vehicles in distribution grids: Lowering the barriers for a proactive integration. Energy 2017, 134, 458-468. [CrossRef]

6. Fichera, A.; Volpe, R.; Frasca, M. Assessment of the energy distribution in urban areas by using the framework of complex network theory. Int. J. Heat Technol. 2016, 34, S430-S434. [CrossRef]

7. Wu, F.; Sioshansi, R. A two-stage stochastic optimization model for scheduling electric vehicle charging loads to relieve distribution-system constraints. Transp. Res. B 2017, 102, 55-82. [CrossRef]

8. Hu, J.; You, S.; Lind, M.; Østergaard, J. Coordinated Charging of Electric Vehicles for Congestion Prevention in the Distribution Grid. IEEE Trans. Smart Grid 2014, 5, 703-711. [CrossRef]

9. Energimarknadsinspektionen. Reglering av elnätsverksamheten. Ei.se-Energimarknadsinspektionen. 2018. Available online: https://www.ei.se/sv/for-energiforetag/el/Elnat-och-natprisreglering/ (accessed on 12 December 2018).

10. Statistiska Centralbyrån. Personbilar i trafik efter drivmedel. årsvis 2008-2017. 2017. Available online: https://www.scb.se/ (accessed on 12 December 2018).

11. de Durana, J.M.G.; Barambones, O.; Kremers, E.; Varga, L. Agent based modeling of energy networks. Energy Convers. Manag. 2014, 82, 308-319. [CrossRef]

12. Xiang, Y.; Liua, J.; Liu, Y. Optimal active distribution system management considering aggregated plug-in electric vehicles. Electr. Power Syst. Res. 2016, 131, 105-115. [CrossRef]

13. Ćosić, B.; Krajačić, G.; Duić, N. A 100\% renewable energy system in the year 2050: The case of Macedonia. Energy 2012, 48, 80-87. [CrossRef]

14. Connolly, D.; Lund, H.; Mathiesen, B.; Leahy, M. The first step towards a 100\% renewable energy-system for Ireland. Appl. Energy 2011, 88, 502-507. [CrossRef]

15. Kremers, E.; Durana, J.G.d.; Barambones, O. Multi-agent modeling for the simulation of a simple smart microgrid. Energy Convers. Manag. 2013, 75, 643-650. [CrossRef]

16. EnergyPLAN. 2019. Available online: https://www.energyplan.eu (accessed on 5 March 2019).

17. Lund, H. Advanced Energy Systems Analysis Computer Model Documentation; Version 13; EnergyPLAN: Aalborg, Denmark, 2015.

18. Volpe, R.; Frasca, M.; Fichera, A.; Fortuna, L. The role of autonomous energy production systems in urban energy networks. J. Complex Netw. 2017, 5, 461-472. [CrossRef]

19. SMHI. Naturvårdsverket \& Strålsäkerhetsverket. 2018. Available online: http://strang.smhi.se/extraction/ index.php (accessed on 5 March 2019).

20. Parkeringsnorm; Karlstad Kommun: Karlstad, Sweden, 2018.

21. Normalladdare för elfordon. 2019. Available online: https://new.abb.com/ev-charging/sv/ (accessed on 5 March 2019).

22. Wang, L.; Sharkh, S.; Chipperfield, A. Optimal decentralized coordination of electric vehicles and renewable generators in a distribution network using A* search. Electr. Power Energy Syst. 2018, 98, 474-487. [CrossRef]

(C) 2019 by the authors. Licensee MDPI, Basel, Switzerland. This article is an open access article distributed under the terms and conditions of the Creative Commons Attribution (CC BY) license (http://creativecommons.org/licenses/by/4.0/). 